\title{
How to Better Construct the National Image through the Party's Image Construction
}

\author{
Yu Jiangting \\ School of Marxism \\ Wuhan University of Science and Technology \\ Hubei Wuhan 430065 \\ E-mail:470791401@qq.com
}

\begin{abstract}
With the progress in China's building of a well-off society and the continuous improvement of its international status, it is imperative to strengthen both domestic and international recognition of our party and country. The article shed light on the relationship between the images of the party and the country, and analyzes their similarities and differences so as to enable the author and readers to get to know how to use the relationship between the party and the country to better promote the image construction of the party and the country.
\end{abstract}

Keywords_Party image; national image; relationship

With the international status promotion of China and the deepening of reform and opening up, study on the image of the party and the image of the country has received increasing attention. The issue of the party's image and national image is theoretical and realistic.

I. THE RELATIONSHIP BETWEEN THE IMAGE OF THE PARTY AND THE IMAGE OF THE COUNTRY

The Communist Party of China is the ruling party of the country, the core leadership for the cause of socialism with Chinese characteristics, and represents the fundamental interests of the Chinese people. Therefore, the image of the party is the most dominant and authoritative component of the national image and determines the image of the country. However, the party's image and national image are also different in terms of display and scope. Here I will explain their homology from the historical context and theoretical basis, and also clarify them from their focal points and natures.

\section{A. Consistency of the party's image and national image}

Whether it is the image of the party or the image of the country, it is basically the image of China sharing the same root of splendid traditional culture of China with a long history of 5,000 years. And they all grow in the theoretical practice of combining Marxist theory with Chinese reality.

\section{a) Same origin}

The party and the whole country are all growing by inheriting and carrying forward the traditional Chinese culture. The thousands of years have witnessed the born of Confucianism, the contending of the schools of the pre-Qin Dynasty, the development of Confucianism, Buddhism and
Taoism in the Sui and Tang Dynasties, and the rise of NeoConfucianism in the Song and Ming Dynasties. Along with that, there emerged such traditional virtues as benevolence, righteousness, rite, wisdom, trustworthiness, loyalty, filial piety, honesty, and shame which still influence people's thoughts and guide people's lives.

History is the best textbook that lets us know the past. It is also the best alarm to inform us to recognize the present situation. Xi Jinping has made a perfect historical interpretation of China's image positioning in his speech in Belgium. He said: "The more than 5,000 years of Chinese civilization, the 170 years of resisting in modern times, the Chinese Communist Party's 90 years of struggle, the People's Republic of China's 60 years development and more than 30 years of reform and opening up, these histories share the same vein and are inseparable. It is hard to have a clear understanding of China if we separate from the history of China, separate from the Chinese culture, separate from the spiritual world of the Chinese, or separate from the profound changes of contemporary China." [1] The "five nouns concerning China" link the party's image with the national image on a historical level.

\section{b) Same theory basis}

The construction of party's image and the national image need to be practiced in reality. And we should guide the practice with the theory. Marxism, Mao Zedong Thought, Deng Xiaoping Theory, the important thought of the "Three Represents", the scientific development outlook, and Xi Jinping thought on socialism with Chinese characteristics for the new era are the guiding ideology of the Communist Party of China and the guide for the construction of socialism with Chinese characteristics. As a socialist country, China applies Marxist theory to its construction, development and reform, and party building and leadership. Therefore, the image of the party and the image of the country are consistent in the theory on which they are built.

\section{B. Difference of the party's image and national image}

The party's image and national image are highly consistent in many respects, but there are also many differences in their content and the focus of construction. What we need to pay attention to is that the improvement of the party's image and the country's development does not mean the improvement of the national image. The good reputation of the national image does 
not mean that there is no need to improve the party's image as the evaluation criteria and scales of the two images are different.

\section{a) Different connotations}

The image of the party has distinct class attributes. It impresses people with the party's class attributes, spiritual outlook, behavior, etc. It is a direct or indirect overall view of the party's ruling philosophy, governing ability and ruling performance, and also a comprehensive evaluation of the Chinese Communist Party's world reputation. The class attribute of the party's image determines that people are the masters of the country. The behavior determines that the comprehensive and strict administration of the party is an important manifestation of the party's image building.

The national image has distinct national characteristics and is linked to the politics, economy and culture of a country. Most people will regard the French passionate and romantic, the Japanese diligent and dedicated, the Germans practical and rigorous, while the Chinese are conventional and conservative. Although these impressions left on the public are not complete, but they prove the distinctive features of the national image in the context of information globalization. Therefore, if a country wants its image to have certain influence, it must first have a distinct national color and leave a deep impression on the world.

\section{b) Different Emphases}

Both the party's image and the country's image are important inside and outside China, and they should be refined internally and externally. However, in the actual propaganda and construction, they have different problems and different construction angles. The party's image is mainly publicized by party organizations at all levels, leading cadres at all levels, and party members. For the people, the leading cadres are the core, and the quality of party members also matters.

In contrast, the scope of the national image is relatively broader and more extensive. It is a system engineering to foster national image from top to bottom and from inside to outside which requires the participation and support of the party, the government and the society. Specifically, the image of the country is reflected in the overall strength of the country, and also in the ideologies and qualities of the citizens.

The criteria and scale of evaluation are another difference between the image of the party and the national image. The image of the party influences the building and development of the party while the effective operation of the party is inseparable from a good image of the party. China's national governance has entered a new stage with various reforms entering the deep water area where tough challenges cannot be avoided, which have put forward higher requirements for the party's image building. Concerning problems such as corruption and unreasonable systems, how to solve and to what extent can we achieve is an important criterion for us to measure the image of the party.

As China has increasingly moved to the center of the world stage, various praises and smearing of China came out as "China threat theory", "China's irresponsibility theory",
"China free rider theory", etc. which are often found in international reports, causing many doubts and misunderstandings about the image of our country. Facing with this situation, we need to not only strengthen the "self-image" but also set good images for the world.

\section{HOW TO BETTER REFLECT THE IMAGE OF THE PARTY IN SHAPING THE IMAGE OF THE COUNTRY}

At the beginning of this century, with the development of "BRICS" and "Belt and Road", China's influence in the international community has been rising and it has attracted more international cooperation. Besides, the image of the Communist Party of China has been improved in an all-round way. However, there are still many "stereotypes" hindering the improvement of the party's image in the international arena, such as socialist countries that are not democratic enough, the poor religious and human rights conditions, and the bad ethics of leading cadres. Therefore, how to better display the party's image while shaping the image of the country is an urgent problem to be solved at the moment.

\section{A. National undertakings require party leadership}

To build a national image, we must adhere to the correct political direction, and follow the leadership of the Communist Party of China in all aspects of the construction of the country's image. Members of the society will always have more or less a clear or ambiguous, or comprehensive, or biased view of the country's image. These ideas and ideas collide with each other, and different values influence each other in various fields, impeding the construction of the national image. Therefore, we need to consolidate the guiding position of Marxism in the field of ideology and affirm the party to be the core leadership in the cause of socialism with Chinese characteristics.

To build a socialist cause with Chinese characteristics, we must implement the overall layout of the "five in one" including economic construction, political construction, cultural construction, social construction, and ecological civilization construction. The CPC shoulders the great responsibility of realizing the great rejuvenation of the Chinese nation. Whether it is building a well-off society in an all-round way, or the requirement of the "five in one" general layout, we must firmly grasp the party's top priority in governing and rejuvenating the country, and implement the party's measures and policies. Under the leadership of the Communist Party of China, the cause of socialism with Chinese characteristics will surely go better and wider, and consequently, our party members and cadres, the people and even the international community will think highly of the party.

\section{B. The construction of a democratic countryneeds to be centered on the people}

Improving the cohesiveness of the country's image and the reputation of the country's image in the world requires the state not only to attach importance to moral democracy, but also to implement democracy through a series of institutional systems to enable people to feel the democracy rather than just hear of it. Therefore, China must constantly improve its political system and strive to improve the government's service capabilities, 
service awareness, and service quality so that every citizen can feel the democratic atmosphere of the government. In this way, our country's people will unite and the party's image can be steadily improved. .

The position of the people is the fundamental stand of Marxism, and the view of the masses is the basic view of Marxism. This position and viewpoint have always run through the construction of the national image, which also better reflects the spirit of the party to maintain flesh-and-blood ties with the people. In August 2013, when Xi Jinping was inspecting in Liaoning, he stated: "Let the people live a good life is the starting point and the foothold of all our work." [2] It can be concluded that on the road of building socialism with Chinese characteristics, the ultimate goal of our government is to seek benefits and happiness for the people. The foundation of the party and the country is the people and the strength is coming from the people. It is the consistent position of our government to go from the perspective of the people. Respecting the people and defending the rights and interests of the people will enable the Chinese people to enjoy the respect of the country, especially the foreign people. The improvement of the international status of the Chinese people is also an inexhaustible motive force for the Chinese Communist Party to work hard.

\section{The construction of a country under the rule of law needs strict party discipline}

In December 2014, the general secretary Xi Jinping put forward the four comprehensive strategic ideas, and demanded ruling over the Party discipline in an all -round way. Later on 27th, October 2016, the Sixth Plenary Session of the 18th Central Committee of the Communist Party of China passed the "Regulations on Inner-Party Supervision of the Communist Party of China". These measures not only marked that the party discipline strengthening has been lifted to the strategic position of the management of the modernization of the country, but also exerted great importance on the maintenance of the party's progressiveness and purity.

Throughout the history, it is not difficult to find that the major nodes of the rule of law are very consistent with the development and change in China. In order to maintain China's sound and sustainable development, the standard of conduct for the rule of law must always be placed in the heart of the government. China has been a society of human relationships since ancient times. Since the founding of New China, many feudal ideas have not been completely eradicated. The idea of "human relationship goes beyond logic, and law falls behind people" has always been rooted in the hearts of the people, which has not only brought trouble to the party's image building, but also smeared China's international image. The country can't develop comprehensively without ruling in accordance with the law. And the government can't be stable without strict party discipline.

\section{THIRD, HOW TO BETTER BUILD A NATIONAL IMAGE IN BUILDING THE IMAGE OF THE PARTY}

Under the leadership of the Communist Party of China, the cause of socialism with Chinese characteristics has achieved important achievements in all aspects: "sustainable and rapid economic development, significant progress in reform and opening up, improvement in people's living standards, new steps in building democracy and the legal system, and cultural development, new progress in social construction, new developments in national defense and army building, further strengthening of Hong Kong, Macao and Tai wan undertakings, new achievements in diplomatic work, and comprehensive strengthening of party building" [4]. We can see that party building plays a vital role in building a national image.

\section{A. Insist on deepening reform and building an innovative country}

The economic base determines the superstructure, so the economic base is the key to shaping the image of the country and the necessity for China to promote the image of our country to the world. To this end, China must unswervingly implement the strategic idea of centering on economic infrastructure, vigorously developing productive forces, and persisting in development to lay the material foundation for a good image of the country.

Deepening reform requires our innovations and the combination of theory and practice. It can be witnessed that China's economy grows faster than any other countries' in the world. But lying behind this rapid development of the economy is environmental pollution and energy waste. Therefore, we shall not maintain the current situation of the country's economic development, and we must make innovation, seek different economic development models, and achieve the highest efficiency with the lowest input, energy consumption and pollution. We will implement socialist modernization and build an innovative country in all aspects with our party playing a leading role. With the guidance of the market, the technological innovation in the major enterprises, and the academic innovation of the national scientific research institutions and major universities will promote the development of productivity. With the support of our government, we must gradually remove the bad tag of "Made in China" and gradually let the high-end "China's creation" that is innovative, and environmental friendly go to the world.

\section{B. Carry out the core values of socialism and build a cultural country}

If economic strength is the tough indicator, we can say that cultural resource is the soft indicator for deepening China's national image. To build a cultural country, we must implement the core values of socialism, and inherit and advocate socialist values. The excellent traditional culture of China improves alongside the social development and changes. It has united Chinese people and inspired the people's spirit. And it is the embodiment of the national spirit and promotes the development of society.

In the context of globalization, the priority to embody comprehensive national strength is the traditional culture which is recognized as a green industry with great growing potential. Many developed countries have their own cultural industries, such as the American values of the United States and the American spirit which are spread in the global because of the 
boom of the American cultural industry. South Korea, of which the culture cannot be underestimated, has promoted its culture and made itself as the fifth largest cultural product and exporter in the world. China has the rich and profound cultural resources. But how can we find our culture with Chinese characteristics and transform it into our strength. There is no doubt that China will create legends in culture as it has created glory in the economy. We should implement social values with Chinese characteristics, develop our culture to empower it to occupy a place in the world, show the world our peaceful development and competition in the world, and gradually become a cultural power.

\section{Adhere to peaceful development and build an open country}

China has undergone a peaceful development full of challenges since the reform and opening up. However, our party has been holding high the socialist banner and regarding the peaceful development as the purpose of our country's diplomacy. China has always adhered to the policy of peaceful coexistence and independent policies, and will never seek hegemony or expansion. We believe in peaceful, sharing, winwin, and corporative development, and will always be the guardian and advocate of world peace.

At present, China continues to adopt the five development concepts of "innovation, coordination, green, openness, and sharing” as a guide to promote supply-side structural reform. China's economic reforms have set an example for the structural adjustment of the world economy. The "Belt and Road" initiative has been proposed for five years. The development and results are unimaginable. This is the mutual benefit brought by peaceful development: more than 30 cities along the route have participated in and signed the "Belt and Road" cooperation agreement, and more than 100 countries and international organizations have assisted it which has gained acknowledgements of the United Nations and many other international organizations. The Belt and Road Initiative has expressed recognition. Financial cooperation like Silk Road Fund and AIIB are continuing to deepen, and a large number of projects of excellent quality have taken root. General Secretary Xi Jinping's “One Belt, One Road" initiative to create brilliance will bring more benefits and allow each stake holders to generate more interests. We should not only link the development of China with the development of countries along the route, but also unite the people along the "Belt and Road".
It can be seen from the above that in the win-win cooperation, the Chinese government has assumed the responsibility of a big country. This is the correct way and result of peaceful development.

\section{CONCLUSION}

By comparing and analyzing the party's image and national image, this paper displays that they have historical characteristics and theoretical basis, entertain Chinese characteristics and follow the Marxist theory. So we cannot view their images separately. While paying attention to the connection between them, we should also note that the party's image and national image also have many differences in nature and construction focus, and the evaluation criteria and scales. Therefore, we must pay attention to the consistency and difference between the two in the construction of the party's image and national image. While constantly improving the "self-image", the national image viewed by others will be gradually optimized to achieve the win-win in party's image and national image.

\section{REFERENCES}

[1] President Xi Jinping's speech at the European Academy in Bruges, Belgium [OL], www.zgdsw.org.cn,2014-0402,http://www.zgdsw.org.cn/n/2014/0402/.

[2] Xi Jinping emphasized during his inspection in Liaoning: Deep implementation of innovation-driven development strategy [EB/OL].http:/www.chinanews.com/gn/2013/09-01/5230492.shtml, 2013-09-01.

[3] Unswervingly marching along the road of socialism with Chinese characteristics, striving for building a well-off society in an all-round way [N]. Renmin ribao, 2012-11-9.

[4] Liu Ming. The Positioning and Spread of Contemporary Chinese National Image [M].Foreign Languages Press, 2007.

[5] Li Zhi. Chinese national image [M]. Beijiing: Xinhua Publishing House 2011.

[6] Xi Jinping. Xi Jinping talks about governing the country [M].Beijing: Foreign Languages Press, 2014.

[7] Zhang Hao, Tang Hongjie. On the Connotation, Performance and Function of the Party's Image [J]. Theoretical Exploration, 2007(3).

[8] Yuan Sainan. On Xi Jinping's National Image Thought [J].Socialism Study, 2017(2). 